Federal Reserve Bank of Minneapolis

Quarterly Review

Winter 1981

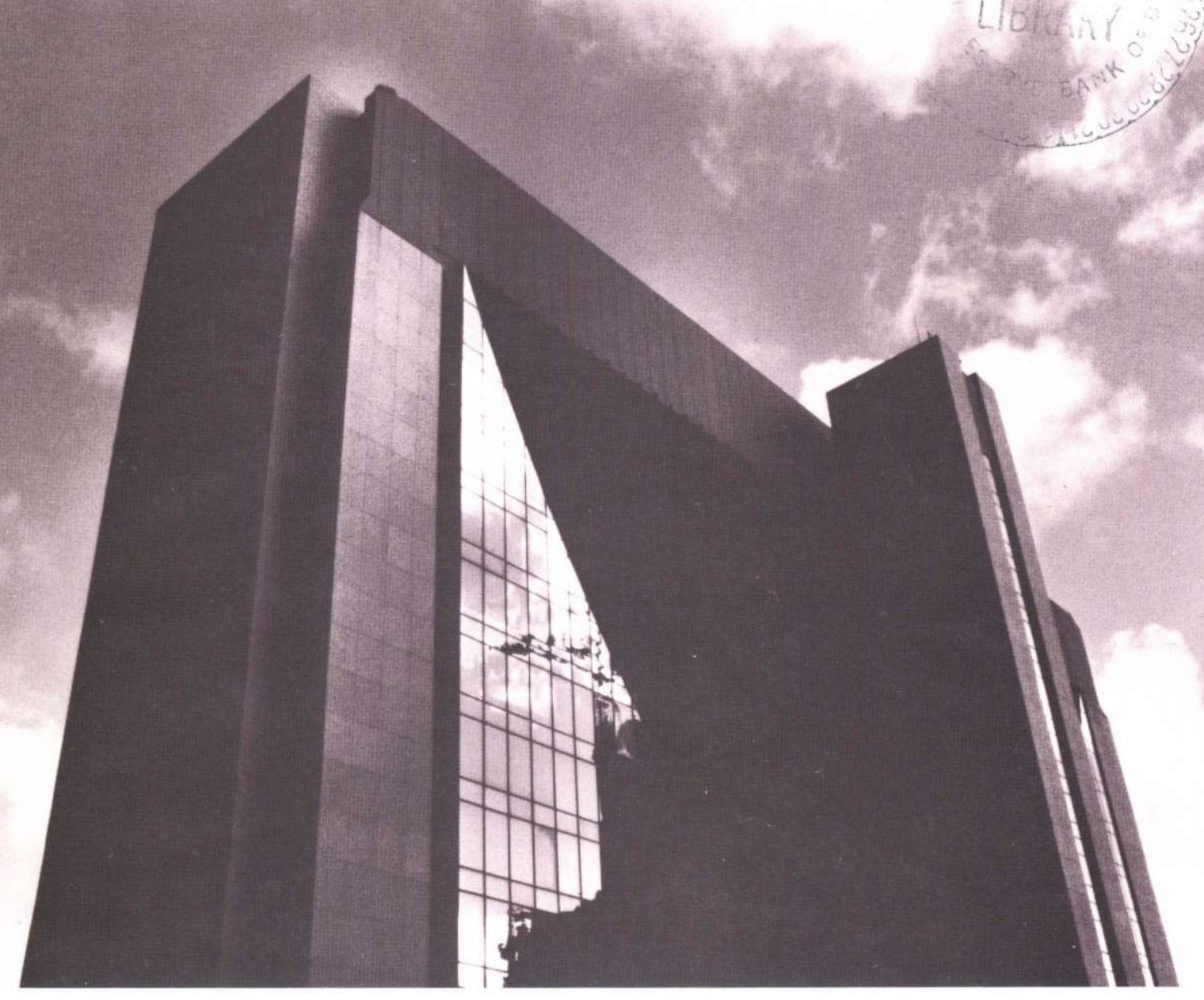

Limited Branching in Minnesota:

Its Impact on Banking Consumers (p. 1)

Commercial Banking as a Line of Commerce:

An Appraisal (p. 7)

District Conditions (p. 14)

1980 Contents (p. 16) 


\section{Federal Reserve Bank of Minneapolis Quarterly Review vol. 5, No.1}

This publication primarily presents economic research aimed at improving policymaking by the Federal Reserve System and other governmental authorities.

Produced in the Research Department. Edited by Arthur J. Rolnick, Kathleen S. Rolfe, and Alan Struthers, Jr. Graphic design and charts drawn by Phil Swenson, Graphic Services Department.

Address requests for additional copies to the Research Department,

Federal Reserve Bank, Minneapolis, Minnesota 55480.

Articles may be reprinted if the source is credited and the Research

Department is provided with copies of reprints.

The views expressed herein are those of the authors and not necessarily those of the Federal Reserve Bank of Minneapolis or the Federal Reserve System. 


\title{
Commercial Banking as a Line of Commerce: An Appraisal*
}

\author{
John H. Kareken, Adviser \\ Research Department \\ Federal Reserve Bank of Minneapolis \\ and Professor of Economics \\ University of Minnesota
}

My purpose in this brief essay is to present a critique of the Supreme Court's ruling, to be found in various of its bank merger decisions, that commercial banking is a line of commerce. That phrase line of commerce appears in Section 7 of the Clayton Act, one of our two basic antitrust statutes, and no doubt that explains why the Court has persisted in using it and why, despite the awkwardness of the expression, commentators have too. But a line of commerce is a product market, and there is more to any such market than a group of producers. Indeed, it is not possible to identify the producers of a particular market without first having identified products and, if perhaps only to determine geographical boundaries, the buyers of those products. Where a merger is at issue, though, who the producers are is crucial, and it is clear how the Court's cryptically put judgment, that commercial banking is a line of commerce, should be read: in any bank merger case the relevant producers are the commercial banks of the appropriate geographical area, whatever it may be; or, in yet other words, the proposed merger of any two commercial banks is to be judged by how it affects the market shares of the commercial banks of the appropriate area.

In appraising the Supreme Court's judgment, I pay particular attention to its 1974 decision in the Connecticut National Bank case. ${ }^{1}$ That decision, although handed down more than six years ago, is still our most

*The author wrote an earlier paper on the same subject which appeared in Commercial banking as a line of commerce, a study done by $\mathrm{Carter} \mathrm{H}$. Golembe Associates, Inc., and published by the Association of Bank Holding Companies (Washington, D.C., 1981). This article is a substantially altered version of that paper. recent observation on its thinking about mergers of commercial banks. It is not a model of either clarity or completeness. But as I suggest in the first section of this paper, what the Court seems to have argued was that Connecticut commercial banks of the early 1970 s were not specialty shops but department stores, indeed, the only department stores of finance, and that commercial banking was therefore a line of commerce. My contention, elaborated in the second section, is that the argument is a non sequitur. There may well be advantage in being a department store of finance, or in providing a unique cluster of products. The actual extent of the advantage can be revealed, though, only by an investigation of what is going on in the real world. So the Court should have investigated, or directed the district court to investigate again, what was going on in Connecticut, and not in some ill-defined single market for commercial bank products, but rather in each of several different markets in which commercial banks were operating. It did not, and that is why it must be faulted for its line-of-commerce judgment.

The world of commercial banks is very different now from what it was in 1974 , in part because the Depository Institutions Deregulation and Monetary Control Act of 1980 was added to our statute books. As many have observed, that act is extremely farreaching, and in the last section of this paper I comment briefly on what it means for bank mergers. It is, I argue, of immediate relevance, since it eliminates legal barriers to entry into certain markets for depository insti-

'United States v. Connecticut National Bank, 418 U.S. 656 (1974). 
tutions other than commercial banks; and it hardly matters that some of those other depository institutions may for years remain only potential competitors of commercial banks.

\section{How the Supreme Court Came to View Banking as Unique}

In 1973, the district court considered a Department of Justice challenge to a proposed merger of two commercial banks, Connecticut National Bank and First New Haven National Bank. ${ }^{2}$ It ruled against the Department of Justice and, interestingly enough, maintained that savings banks had to be included, along with commercial banks, among the relevant producers. Connecticut savings and commercial banks were, it said, in some degree "fierce competitors" (p. 280). There was "meaningful competition" between the two kinds of banks in the provision of a variety of products. When the decision was appealed, however, the Supreme Court overruled the district court. It found, as it had previously, that commercial banking was a line of commerce. The question is how the Supreme Court came to its judgment that, in Connecticut during the early 1970s, commercial banking was a line of commerce.

It appears to be widely accepted that the Supreme Court's Connecticut National decision followed from its 1963 decision in the Philadelphia National Bank case ${ }^{3}$ but that, I believe, can reasonably be disputed. The line-of-commerce arguments of the two decisions would appear to be different.

In its Philadelphia National decision, the Supreme Court argued in what seems to me a straightforward way. I do not say that it was convincing, but only that it proceeded as economics suggests it should have. It considered separately, one at a time, a variety of the more important different products provided by commercial banks and for each gave a reason why in providing it commercial banks were sufficiently insulated from competition. To quote from the Philadelphia National decision (pp. 356-57):

Some commercial banking products or services are so distinctive that they are entirely free of effective competition from products or services of other financial institutions; the checking account is in this category. Others enjoy such cost advantages as to be insulated within a broad range from substitutes furnished by other institutions. ... Finally, there are banking facilities which, although in terms of cost and price they are freely competitive with the facilities provided by other financial institutions, nevertheless enjoy a settled consumer preference, insulating them, to a marked degree, from competition; this seems to be the case with savings deposits.

In that instance, then, commercial banking was a line of commerce because, for a variety of reasons and over a range of different products, commercial banks were not really confronted by genuine competitors.

Surprisingly perhaps, the Supreme Court did not go on at great length about line of commerce in its Philadelphia National decision. Besides the above-quoted passage, there is hardly more than one other dealing with line of commerce (p. 356):

We have no difficulty in determining the "line of commerce" (relevant product or services market). . . . We agree with the District Court that the cluster of products (various kinds of credit) and services (such as checking accounts and trust administration) denoted by the term "commercial banking". . . composes a distinct line of commerce.

What the district court had said in this case ${ }^{4}$ was that "[c]ommercial banks are the only institutions authorized to receive demand deposits," or, in words it might better have used, that they are the only institutions authorized to provide payments services, and further, that they "offer a wider variety of services than any other financial institutions." Commercial banks, it noted, "have often been termed the department stores of finance" (p. 360). Its argument apparently was that, being department stores of finance, commercial banks were by themselves a line of commerce. There is some substantiation of that in the following passage taken from the district court's decision (p. 363):

It is the conglomeration of all the various services and functions that sets the commercial bank off from other financial institutions. Each item is an integral part of the whole, almost every one of which is dependent upon and would not exist but for the other. ... .

${ }^{2}$ United States v. Connecticut National Bank, 362 F. Supp. 240 (1973).

${ }^{3}$ United States v. Philadelphia National Bank, 374 U.S. 321 (1963).

${ }^{4}$ United States v. Philadelphia National Bank, 201 F. Supp. 348 (1962).

${ }^{5}$ That second sentence is blatantly false and best forgotten. At the time of the decision, neither savings banks nor savings and loan associations could legally provide payments services. So if that sentence were true, there would have been no savings banks or savings and loan associations in existence. 
It is one thing, though, to say, as the district court evidently did in its Philadelphia National decision, that commercial banks were department stores of finance, and therefore, taken together, a line of commerce. It is something else to say, as the Supreme Court did in its Philadelphia National decision, only that the cluster of products being provided by commercial banks was a line of commerce. In its Philadelphia National decision the Supreme Court seems to have found commercial banking to be a line of commerce not because commercial banks were (the only) department stores of finance, but because in the provision of many important products they were not facing genuine competition, except maybe from each other.

In its Phillipsburg National Bank and Trust Company decision, ${ }^{6}$ however, the Supreme Court did bless the district court's line-of-commerce argument that commercial banking was a line of commerce because commercial banks were department stores of finance. And looking back from 1974, it appears a good thing that it did. In 1974, more than a decade after it had handed down its Philadelphia National decision, and with its collective eye on Connecticut rather than Pennsylvania, it could not maintain that, with regard to savings deposits, commercial banks enjoyed a settled consumer preference. In its Connecticut National decision it conceded that the district court had been in part right in its observation that savings and commercial banks competed fiercely: "[W]e have no doubt on [the] record that savings banks and commercial banks are 'fierce competitors' ... to the degree that they offer identical or essentially fungible services"' (p. 662). But as I indicated, it had blessed the district court's Philadelphia National argument in its Phillipsburg National decision, and in its Connecticut National decision it quoted the relevant passage from that decision (p. 664):

Philadelphia Bank emphasized that it is the cluster of products and services that full-service banks offer that as a matter of trade reality makes commercial banking a distinct line of commerce. Commercial banks are the only financial institutions in which a wide variety of financial products and services-some unique to commercial banking and others not-are gathered together in one place. The clustering of financial products and services in banks facilitates convenient access to them for all banking customers.

That is quite a clear statement: Commercial banks provide a broader range of products than do any of the other differently designated financial institutions; they provide most if not all of those provided by other institutions and some that the others do not (cannot) provide. They are truly the department stores of finance, and that is why they are special and, taken together, a line of commerce.

\section{A Basis in Law}

The Supreme Court's Connecticut National decision is to be distinguished, though, from its Phillipsburg National decision. In the Conrecticut decision the Court put more stress than it had in the Phillipsburg decision on the legal authority of commercial banks. Thus, it took notice of a recently enacted Connecticut statute ${ }^{7}$ and pointedly remarked on what that statute did not authorize. Savings banks, it said, would soon be able to provide payments services to individuals but not to business customers (pp. 665-66):

The state statute empowering savings banks to offer demand deposits forbids those banks from marketing the service to anyone "for the purpose of, or in connection with, the carrying on of any business, trade, occupation or profession." . . . Thus, under the new act, savings banks will be restricted to offering personal checking accounts.

So, even under the new statute, Connecticut commercial banks would still be unique. They would still be, taken together, a line of commerce. To quote again from the Connecticut National decision (p. 664):

Despite the strides that savings banks in [Connecticut] have made toward parity with commercial banks, the latter continue to be able to provide a cluster of services that the former cannot, particularly with regard to commercial customers, and this Court has repeatedly held that it is the unique cluster of services provided by commercial banks that sets them apart for purposes of [Section] 7 [of the Clayton Act]. (Emphasis added.)

And had legal restrictions not seemed important to the Court, it presumably would not have used the word cannot. The words do not would have been more appropriate.

In stressing the legal authority of commercial banks, the Supreme Court was (as young folks used to say) (1970)

${ }^{6}$ United States v. Phillipsburg National Bank and Trust Co., 399 U.S. 350

${ }^{7}$ Connecticut Public Act 73-195 (May 14, 1973). 
right on. For a successful antitrust challenge to a merger, past or proposed, barriers to entry are of the essence. If there are none, then the notion that the merger poses any threat to competition is pure fantasy. And a legal restriction such as that cited by the Court in its Connecticut National decision is, pure and simple, a barrier to entry.

Even though not all statutes are effective, there still is a big difference between an appeal to history, to who has been producing what, and an appeal to legal restrictions on entry. Where a merger is at issue, who has been producing what has no necessary implications. Imagine that there are two companies and that all along they have been the only producers of some particular product. They have decided to merge, and the question is whether they ought to be allowed to go ahead. By itself, the fact that they are and have long been the only producers is not compelling. It may always have been easy to get into their business. Other companies may have stayed out simply because, with the two of them producing, there was no money to be made in their business.

In its Connecticut National decision the Supreme Court did observe, as it had in prior decisions, that some products were being provided by commercial banks alone (p. 665):

[T] he commercial bank-loan business in Connecticut is controlled almost exclusively by commercial banks. Moreover, commercial banks in the State offer credit-card plans, loans for securities purchases, trust services, computer and account services, and letters of credit. Savings banks do not.

That, however, is not a very revealing or helpful observation. Savings banks may not have been providing some or all of the listed products because there was no profit incentive for them to do so. If that is the explanation, they may still have been, in a very real sense, competitors of commercial banks in the markets for those products. But the Court did make an undeniably material point when it noted that Connecticut savings banks were by law prevented from providing payments services to commercial customers.

The intent of the Court, though, in stressing the legal authority of Connecticut commercial banks, seems only to have been to establish that they provided a broader range of products than any other differently designated financial institutions: Again, its argument was in es- sence this: there were some products that by law only commercial banks could provide; and since commercial banks provided most, if not all, of the products provided by the other institutions, theirs was the broadest range of products, a unique cluster of products.

There remains the question, to which I now turn, of how the Supreme Court got from its observation that Connecticut commercial banks were providing a unique cluster of products to its conclusion that commercial banking was a line of commerce.

\section{Why Banking Can Be Unique and Still Not Be a Line of Commerce}

It very well may be that there is advantage, a generalized advantage, extending to all other products, in being able to provide some products that by law others cannot. So far as I know, there are no analyses of the possibility to be found in the economics literature. ${ }^{8}$ But it is not inconsistent with postwar history. Why have savings banks and savings and loan associations been allowed to pay more interest than commercial banks on certain kinds of liabilities? And why have savings bank and savings and loan association officials labored so to preserve their interest rate advantage?

Nor is it difficult to think up reasons why Connecticut commercial banks of the early 1970 s, being able to provide products that differently designated financial institutions could not, were therefore at a competitive advantage in the provision of other of their products. In providing payments services, commercial banks may have acquired information about their customers, information that they were able to make good use of when the customers changed hats and showed up as would-be borrowers. The provision of payments services could also have given advantage in the marketing of other products. It does not hurt to be well-known.

${ }^{8}$ Commercial bank loan and investment policy (Urbana, Ill.: University of Illinois, 1963), by Donald R. Hodgman, a book which appeared after the district court's Philadelphia National decision and before the Supreme Court's, does not contain such an analysis. History has overtaken Hodgman, but his essential point was that commercial banks, because they alone provide payments services (or demand deposits), are unlike "institutional investors." Allegedly, they have a different portfolio strategy and, in their lending, a different pricing policy. Perhaps, but being different is not the same as having a competitive advantage. And Hodgman does not explain in any detail why commercial banks, having "a virtual monopoly on the services which institute the national payments mechanism" (p. 170), are (or were) therefore at an advantage in the provision of other products. He may not have believed this, although he does seem to have argued for commercial banking as a line of commerce (pp. 169-73). 
But what the Supreme Court emphasized in its Connecticut National decision was the convenience of one-stop shopping: "The clustering of financial products and services in [commercial] banks facilitates convenient access to them for all banking customers" (p. 664). And convenience explains the existence of supermarkets and department stores and shopping malls. That being so, it is certainly reasonable that in the early 1970 s Connecticut and other commercial banks were able to trade on the relatively great convenience that only they could offer.

It does not follow, though, that commercial banking was therefore a line of commerce, whether in Connecticut or elsewhere, unless commercial banks were insulated from competition even in the provision of products also provided by differently designated financial institutions. Suppose that there are two ordinary department stores located very near. The first carries, say, 100 different products, and the second carries that 100 and another 10. The two stores are, so to say, in the same business. But who would argue that the second can charge whatever it wants for any of the 100 products carried by both stores? Having that additional 10 products, making one-stop shopping more nearly possible, may give some market power. But how much power is something to be determined empirically. Excessive market power, or overwhelming competitive advantage, simply does not follow as a matter of logic from providing greater convenience.

My example may appear too contrived. I have not explained why the first store does not carry those other 10 products. It is possible, though, to invoke a legal barrier to entry, as the Supreme Court did in its Connecticut National decision. But again, convenience, like most other things, is worth only so much. (And what it is worth may be offset, either in part or completely, by the cost of providing it.) In giving convenience, the provider does not get a license to steal. The shopping strategy that appears most attractive at one configuration of prices will not appear so at another. So what if Connecticut commercial banks, protected by law, were in the early 1970s providing the broadest range of products? The Supreme Court should not have concluded, as a matter of logic, that savings banks were therefore to be excluded from the line of commerce. The presumption that there is sufficient competitive advantage in providing convenience should have been checked against what was going on in Connecti- cut. It is of decided relevance that, as was pointed out above, the Supreme Court accepted in part the district court's finding of fact: "[W]e have no doubt on [the] record that savings banks and commercial banks are 'fierce competitors' . . . to the degree that they offer identical or essentially fungible services"' (p. 662).

\section{Banks compete in more than one market}

It is most perplexing. In its Connecticut National decision the Supreme Court did accept, if only in part, the district court's finding of fierce competition. Yet, undeterred, it found that commercial banking was a line of commerce (p. 663):

As the District Court put it in another context, it would be "ostrich-like" . . . to assume that the two types of banks [commercial and savings] are not in direct and vigorous competition with regard to the services they share or are not viewed by many bank customers as more or less fungible for purposes of those services. . . That savings and commercial banks are direct competitors in some submarkets, however, is not the end of the inquiry, as Phillipsburg makes clear.

It is not easy, though, to make economic sense of that passage. If commercial and savings banks were in direct and vigorous competition, then, in the markets for some products (not all, perhaps, but some), savings banks were among the relevant suppliers. The Court seems to have gotten hung up by insisting on there being only one market. And why it should have is something of a mystery. Can the Court possibly have thought that commercial bank customers buy not the products provided by banks, but rather somehow or in some sense the banks themselves? Or, more generally, that individuals consume not particular products, but companies?

Indisputably, commercial banks are and have long been multiproduct companies. The Connecticut commercial banks of the early 1970s were, and in Connecticut and elsewhere those of the present day are. Nor can it reasonably be maintained that all of the various products of commercial banks are, in the generally accepted sense of the phrase, close substitutes. Some are, but not all. For all bank mergers, the initial or working presumption, the null hypothesis, ought then to be that there are several lines of commerce or several distinct product markets, each with its own group of producing companies and its own geographical area. In any particular instance, investigation may reveal that the commercial banks of the relevant geo- 
graphical area are without significant competitors. Casual observation suggests, though, that the finding is likely to te otherwise. Most commercial banks face different groups of competitors in each of several markets. Until very recently, commercial banks outside New England competed only with each other in their payments-services markets. But with the Depository Institutions Deregulation and Monetary Control Act of 1980 (hereinafter, the 1980 Deregulation Act) having become a part of the law of the land, commercial banks do not have even those markets to themselves.

\section{Deregulation Act further erodes court decisions}

What the 1980 Deregulation Act did was open all payments-services markets to other depository institutions and, most particularly, to savings and loan associations. It also permitted other depository institutions to lend more freely to individuals than previously they could and perhaps, although a certain artfulness may be required, to commercial customers as well. And in recognition of what Congress did in the act, some have advocated simply including savings and loan associations, credit unions, and, where they exist, savings banks among the relevant producers of an undifferentiated something called financial products. Thus, if liabilities (assets) are to be used in calculating market shares, then the liabilities (assets) of such nonbank depository institutions as there are ought to be included in the denominator. That is what has been claimed, and making room for those other institutions could be a step in the right direction, since to all appearances commercial banks do compete with savings and loan associations and savings banks in the provision of some products. What gives me pause is the thought of persisting in the fiction that commercial banks operate in just one market, and that competition in the supply of a variety of different products is well-approximated by how such a heterogeneous aggregate as the total liabilities (or assets) is distributed over a predetermined class of financial institutions.

Having several lines of commerce could force apparently strange decisions in bank merger cases. Even by the standards of the Justice Department, suitably modified, it might be permissible for two large New York City banks to merge, but not for two small banks, located in some out-of-the-way place, to do so. Imagine that there are two banks, would-be merger partners. One is far and away the largest in its state; and the other, very close in footings to the first, is far and away the second largest. Their merger might not seem to be in the public interest. But what if both are mostly in wholesale banking? The markets for large-denomination certificates of deposit and large-corporation commercial loans are worldwide, and the two banks, even after having merged, may have no appreciable market power in them. Because of their emphasis on wholesale banking, they may not have any appreciable power in local financial-services markets either.

There is the possible objection that having several product markets or lines of commerce would be impractical. That, however, is easily rebutted. Having several lines of commerce may not be all that impractical. Consider what Justice Harlan said in his Phillipsburg National dissent (p. 381):

$[\mathrm{T}]$ he Court's choice of a product market here can be seriously questioned. Certainly a more discriminating conclusion concerning the antitrust implication of this merger could be made if separate concentration percentages were calculated for each of the important products and services provided by appellee banks, and then an overall appraisal made of the effect of this merger on competition.

That is from a man who, as a long-time member of the Supreme Court, cannot be dismissed as having had no feel for what is practical. There is a further point. If it is important that the United States have efficient financial arrangements, then putting more time and money than heretofore into bank merger decisions may be justified.

If courts could once have legitimately found the commercial banks of many geographical areas to be without significant competitors, that is most unlikely now. Such has been the change wrought by the 1980 Deregulation Act. Most importantly, the act put savings and loan associations where Connecticut savings banks were at the beginning of 1974. It gave them access to certain markets and, I would argue, must therefore be regarded as having already altered the competitive reality.

As was noted above, the Supreme Court, in its Connecticut National decision, acknowledged the existence of a recently enacted state statute that changed the situation of Connecticut savings banks. Having done so, it then conceded that with the changed situation of the savings banks, the line of commerce might at some point in the future have to be expanded (p. 666): 
We do not say, and Phillipsburg National Bank ... and Philadelphia National Bank ... do not say, that in a case involving a merger of commercial banks a court may never consider savings banks and commercial banks as operating in the same line of commerce, no matter how similar their services and economic behavior. At some stage in the development of savings banks it will be unrealistic to distinguish them from commercial banks for purposes of the Clayton Act. In Connecticut, that point may well be reached when and if savings banks become significant participants in the marketing of bank services to commercial enterprises.

We can, of course, interpret "savings banks" as "other depository institutions," for it is only the peculiar history of Connecticut (or New England) that made the Court focus on savings banks in the Connecticut National case. Even so, it is not clear how much it promised for the future. With the last sentence of the quoted passage in mind, district courts and our banking agencies may for years persist in using commercial banking as a line of commerce. How long will it be before savings and loan associations (and in the East, savings banks) are "significant participants" in the markets that have been opened to them? In some parts of the country, maybe quite a few years.

A case can be made, though, that the Supreme Court should not have imposed the condition of significant participation. The sina qua non of significant market power is barriers to entry. If there are no barriers, then, whatever market shares may be, there is no significant market power. And what the 1980 Deregulation Act did was remove important legal barriers to entry. Now, therefore, all savings and loan associations, even those that have not yet become significant participants in markets that have been opened up to them, are relevant for those markets. They are all of decided relevance, for the threat that a savings and loan association, already well-established in the area, will move into a market is ever so much more real than the threat that another commercial bank will open a new branch.

\section{A Suggestion for Future Bank Merger Cases}

Where a bank merger is at issue, it ought to be accepted that there may be several lines of commerce, or several different product markets, each with its own geographical boundaries and group of companies or suppliers, actual and potential. That is not to say that in every future instance there will be several, for, although that is not an unreasonable surmise, the actual circumstan- ces of each proposed merger must rule. They cannot, though, so long as it is simply taken for granted that commercial banking is a line of commerce.

Having to square the Supreme Court's fateful lineof-commerce finding with their own perceptions of contemporary reality, various district courts have said, if not in so many words, that commercial banking is and is not a line of commerce. Thus, in deciding the 1967 Crocker-Anglo National Bank case, ${ }^{9}$ a district court engaged in shading. That is to say, it first calculated the market shares of commercial banks, but then adjusted the calculated shares to take account of, among other things, competition from differently designated financial institutions. In its decision in the 1970 First National Bank of Maryland case, ${ }^{10}$ another district court said that commercial banking was the line of commerce, but that nonbank competition was to be taken into account in appraising the effects of the proposed merger.

It is bound to be offensive to economists, especially those with tidy minds, having to read that commercial banking is and is not a line of commerce. Surely, commercial banks either are the only suppliers of the relevant products or they are not. But economists do not have to revere the Supreme Court quite as district court judges do, or see it as it must appear from down the judicial ladder, as a brooding presence. And in truth, although detailed analysis is required in every instance of a proposed bank merger, there is nothing in economics that says that the analysis must come before market shares have been calculated rather than after. Whether before or after is less important than whether it is accepted that there may be several lines of commerce or product markets. Even after the most mindless of starts, a proper appraisal is still possible.

${ }^{9}$ United States v. Crocker-Anglo National Bank, 277 F. Supp. 133 (1967).

${ }^{10}$ United States v. First National Bank of Maryland, 310 F. Supp. 157 (1970). 